\title{
Automated Guided Vehicle (AGV) Pengikut Garis Menggunakan Roda Mecanum Dengan Kendali PID Adaptif Terinterpolasi
}

\author{
1,2Justiadi ${ }^{\star}$, 1Jumaddil Hair \& 2 Yusdianto \\ 1,2,3 Politeknik Industri Logam Morowali \\ 1 justiadi.hatta@gmail.com, ${ }^{2}$ joemadil.hair@gmail.com
}

\begin{abstract}
Abstrak
Penelitian ini bertujuan untuk membuat rancang bangun Automated Guided Vehicle (AGV)menggunakan roda omni-directional. Sistem AGV dipandu oleh path guidance dalam bernavigasi. Penelitian ini bersifat kuantitatif. Roda omni-directional tipe mecanum dipasang 4 buah pada AGV. Masing-masing roda dikendalikan oleh motor DC sehingga AGV mampu bergerak ke segala arah secara independent. Sistem path guidance menggunakan sensor garis yang membaca garis putih untuk memandu AGV dalam melakukan proses tools handling dari satu stasiun ke stasiun yang lain. Kendali PID Adaptif terinterpolasi (Interpolated Adaptive PID) digunakan untuk menjaga kestabilan AGV mengikuti garis. Kendali PID ini adaptif karena nilai konstanta PID dipengaruhi oleh besarnya setpoint kecepatan AGV. Fungsi stasiunadalah sebagai tempat menyimpan dan mengambil toolbox. Hasil penelitian menunjukkan bahwa penggunaan 4 roda mecanum dapat diterapkan pada AGV dalam melakukan tools handling. Kendali PID Adaptif terinterpolasi efektif digunakan untuk memandu AGV mengikuti garis dengan kecepatan $(0.5-1.8) \mathrm{m} / \mathrm{s}$.

Kata Kunci: AGV, mecanum, PID Adaptif terinterpolasi
\end{abstract}

\section{Pendahuluan}

Dampak dari revolusi industri 4.0 menciptakan pergeseran konsep di setiap sektor yang terkait. Sejarah menunjukkan, di tengah setiap revolusi muncul kesempatan baru (BPPI). Seperti disampaikan oleh Klaus Schwab (World Economic Forum)bahwa revolusi industri 4.0 ditandai dengan munculnya super komputer, robot cerdas, kendaraan tanpa pengemudi, rekayasa genetik dan perkembangan neurotechnology yang memungkinkan manusia untuk memaksimalkan fungsi otak.

Pada industri manufaktur, terdapat workshop perawatan dan perbaikan. Bahkan dalam workshop tersebut dilakukan pembuatan komponen. Di dalam workshop terdapat banyak mesin kerja seperti mesin bubut, mesin bor, mesin las dan lain-lain yang dioperasikan oleh pekerja workshop.

Bagian penunjang kegiatan perawatan dan perbaikan adalah proses material handling (pemindahan bahan atau alat/tools). Proses material handling ini dapat mencapai 50\% - 70\% dari kegiatan produksi (Apple). Informasi ini memberikan gambaran bahwa kegiatan pada workshop perawatan dan perbaikan membutuhkan banyak pergerakan, terutama proses material handling sehingga penting adanya perancangan sistem material handling. Sekaligus untuk menjawab

tantangan industri 4.0, maka proses material handling harus fleksibel (Wicaksono \& Nilkhamhang).

Material handling umumnya dilakukan secara manual atau menggunakan konveyor, robot tangan, forklift, dan Automated Guided Vehicles (AGV). AGV lebih unggul dibandingkan yang lain dalam hal efesiensi dan fleksibilitas yang dimilikinya (Wicaksono \& Nilkhamhang). Jika dibandingkan dengan menggunakan forklift yang dikendalikan secara manual, AGV mampu memberikan akurasi posisi yang lebih tinggi, operasi lebih lama, pengurangan biaya operasi dan perawatan, dan meningkatkan keamanan (Draganjac et al.,).

Jenis AGV yang banyak digunakan adalah AGV line follower, yaitu AGV yang berpindah dari satu tempat ke tempat lain dengan path guidance yang terletak di sepanjang jalur AGV. Path guidance dapat berupagaris warna, jalur magnet dan laser (Piyare\& Singh).Model navigasipath guidance ini biasanya digunakan untuk sistem AGV yang sederhana. Navigasinya dirancang untuk pola yang statik.

Secara umum desain AGV menggunakan roda standar yaitu roda dengan pergerakan nonholonomic.Pada model seperti ini, pergerakan tidak mampu dikontrol pada setiap tingkat kebebasan dalam bergerak secara independent, sehingga hanya mampu bergerak ke beberapa arah yang sudah ditentukan sebelumnya. Meskipun pada umumnya mampu menjangkau setiap lokasi dan orientasi ruang dua dimensi, namun memerlukan manuver dan perencanaan jalan yang rumit dan kompleks (Barbulescu et al.,). Di lain sisi, perancangan sistem melewati penghalang merupakan tugas yang sulit (Kunet al.,).

Penggunaan roda omni-directional memungkinkan pada AGV dapat bergerak independent ke segala arah dengan mudah tanpa perlu reorientasi. Dengan demikian, AGV mampu melakukan manuver yang lebih tinggi dalam lingkungan yang dinamis (Barbulescu et al.,). Gambar 3 memperlihatkan arah pergerakan AGV jika 
menggunakan roda omni-directional dibandingkan dengan roda standar.
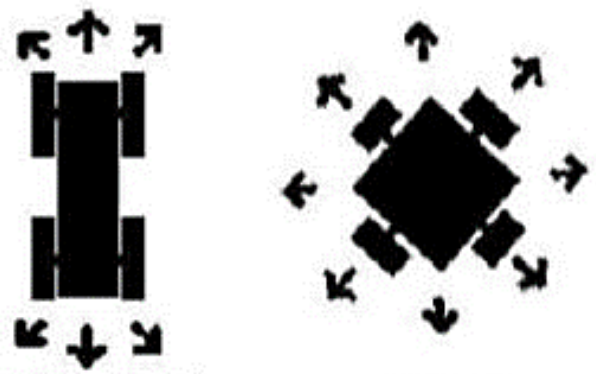

Gambar 1 perbandingan arah pergerakan Sistem AGV dengan roda standar dan roda omni-directional

Banyak penelitian sebelumnya yang meneliti tentang AGV. Dari segi roda penggerak, ada yang menggunakan roda standar (Piyare \& Singh), roda omni (Barbalescu), dan roda mecanum (Tsai). Beberapa algoritma yang biasa digunakan dalam mengendalikan AGV dalam mengikuti garis adalah menggunakan algoritma path tracking (Piyare \& Singh), kendali PID (Gomes), fuzzy logic (Nugraha), cascade PID (Barbalescu) dan lain sebagainya.

Berdasarkan pemaparan di atas, penelitian ini bertujuan untuk merancang bangun Automated Guided Vehicle (AGV) menggunakan roda mecanum. Garis putih di lantai sebagai jalur dan AGV dilengkapi modul sensor garis yang memandu AGV melakukan tools handling. AGV menggunakan kendali PID adaptif dalam mengikuti garis.

\section{Bahan dan Metode}

Penelitian ini merupakan penelitian kuantitatif yang menghasilkan rancang bangun AGV. AGV yang dirancang berfungsi sebagai pengantar tools dari station tools centre ke station mesinCNC atau sebaliknya. Penghubung antar station menggunakan jalur garis putih.

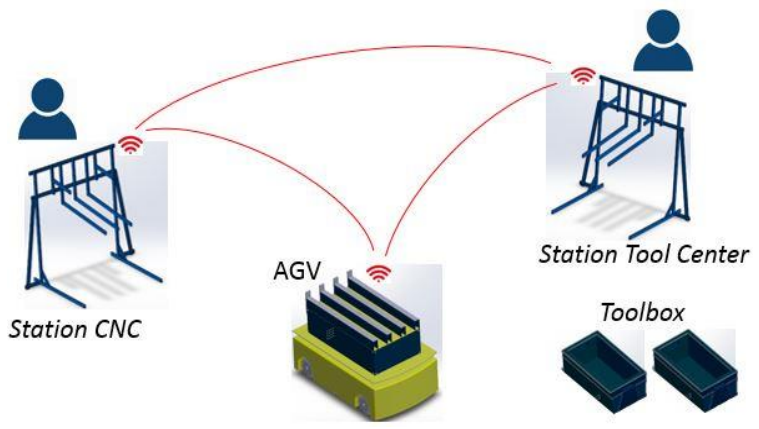

Gambar 2 gambaran umum perancangan sistem
Komunikasi antara AGV dan station menggunakan wireless Wifi. Ketika proses peminjaman alat, operator tools center menyimpan toolbox yang berisi alat yang dipinjam di atas station tools center kemudian memencet tombol station. Informasi dikirim ke AGV dan AGV menuju station untuk mengambil toolbox. Toolbox kemudian diantar ke station CNC.Sebaliknya ketika proses pengembalian alat, operator CNCmenyimpan toolbox yang berisi alat yang dikembalikan di atas station CNC kemudian memencet tombol station. Informasi dikirim ke AGV dan AGV menuju station untuk mengambil toolbox. Toolbox kemudian diantar ke station tools center.

\section{$2.1 \quad$ Flowchart Penelitian}

Penelitian ini dilakukan dalam beberapa tahap. Proses berikut merupakan tahapan-tahapan penelitian yang dilakukan dan terurut dari tahapan awal sampai akhir.

- Mengumpulkan dan mempelajari literatur yang ada yang berhubungan dengan AGV dalam proses material handling.

- Perancangan AGV menggunakan roda omni directional

- Merancang kendali PID adaptif untuk mengikuti garis

- Menguji AGV mengikuti garis

- Merancang station tempat mengambil dan menyimpan toolbox.

- Menguji AGV mengambil dan menyimpan toolbox dictation

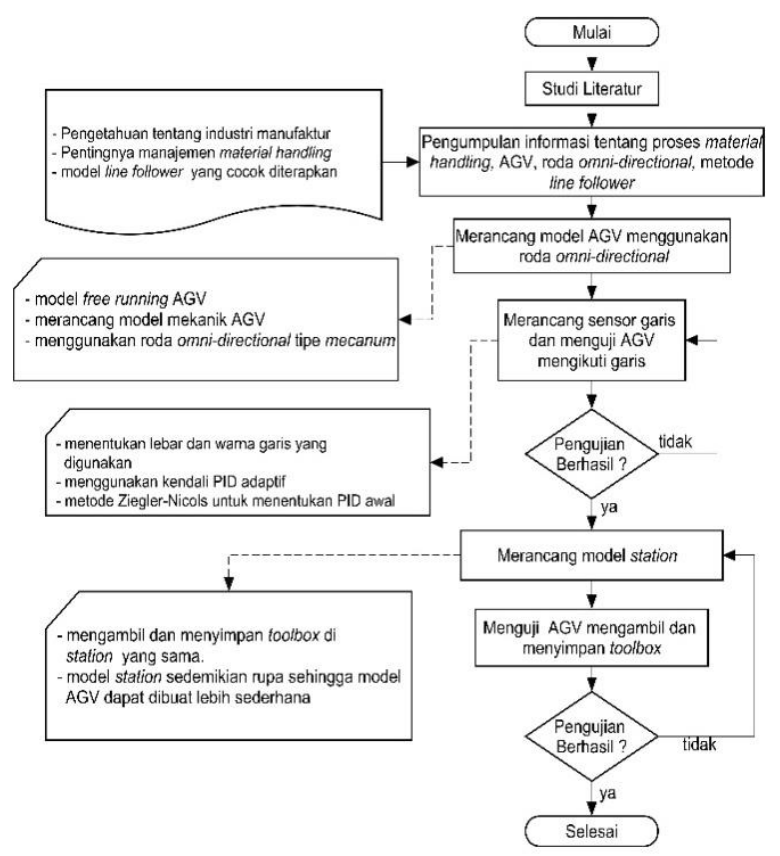


Seminar Nasional Instrumentasi, Kontrol dan Otomasi (SNIKO) 2018 Bandung, Indonesia, 10-11 Desember 2018

Gambar 3 flowchart penelitian

\subsection{Perancangan Mekanik}

AGV yang dirancang berukuran $(80 \times 55 \times 65) \mathrm{cm}$. Menggunakan 4 roda omni-directional tipe mecanum yang berdiameter 5" (152 mm). Rangka utama AGV menggunakan aluminium hollow. Penutup manggunakan pelat AlCoPan (Alluminium Composit Panel). AGV ini dirancang untuk mampu menahan beban maksimal $20 \mathrm{~kg}$.

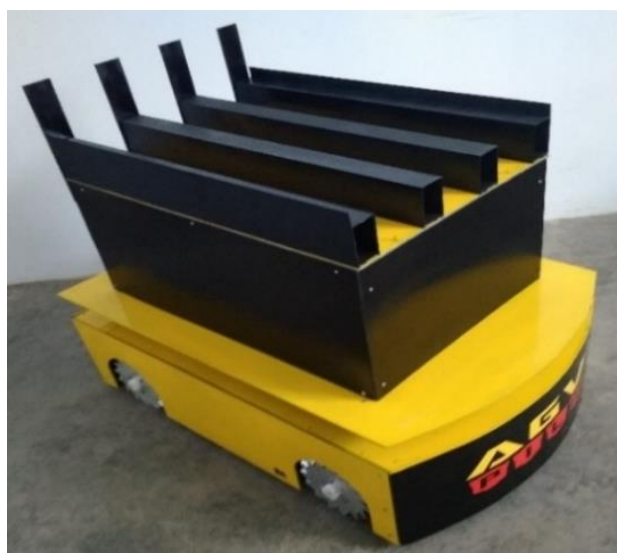

Gambar 4 model mekanik AGV

Pada bagian atas AGV terdapat empat aluminium hollowyang dipasang sejajar dengan jarak tertentu, sehingga ada celah antara aluminium yang satu dengan yang lainnya. Dengan cara yang sama di station terpasang tiga besi hollow yang juga sejajar satu sama lain dengan jarak tertentu dan juga memiliki celah antara besi. Sehingga pada proses pengambilan maupun penyimpanan toolbox pada station, aluminium pada bagian atas AGV dapat lewat di celah besi station. Selain itu pada sisi atas bagian belakang AGV terdapat pelat yang menonjol ke atas, fungsinya untuk mengait toolbox di station.

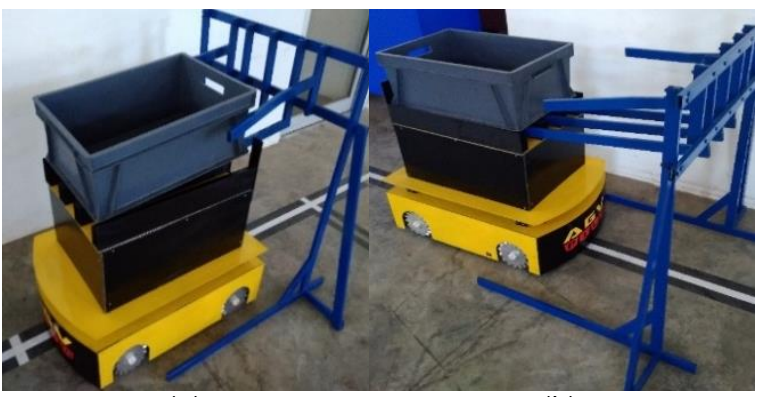

(a)

(b)

Gambar 5 (a) mengambiltoolbox dari station, (b) menyimpan toolbox ke station.

\subsection{Perancangan Elektronika}

Perancangan sistem kontrol AGV dibangun dari 4 bagian utama, yaitu bagian kendali, masukan, luaran, dan power suplai. Blok diagram sistem kontrol AGV memperlihatkan seluruh komponenkomponen elektronika yang digunakan untuk membuat AGV.

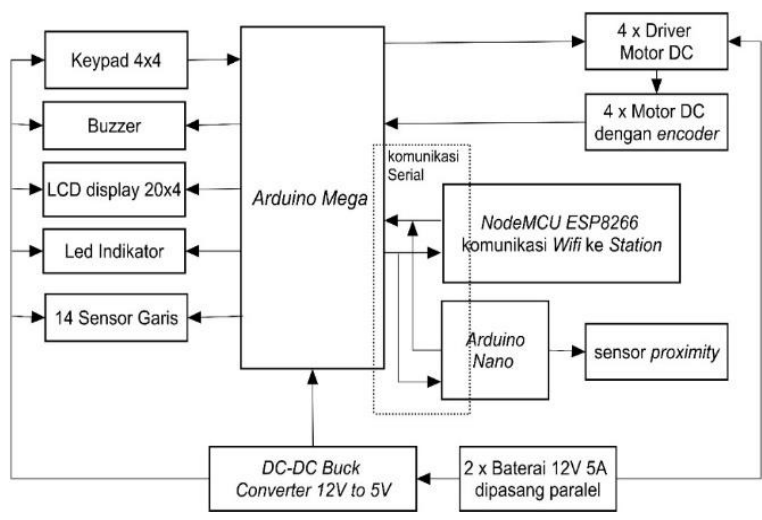

Gambar 6 blok diagram elektronika AGV

Modul kendali menggunakan Arduino Mega sebagai master dan Arduino Nano dan ESP8266 sebagai slave. Motor DC menggunakan motor DC planetary gearbox 45 (PG45) dengan modul BTS7960B sebagai driver motor. Sensor garis menggunakan rangkaian led (transmitter)dan fotodioda (receiver). Modul pelengkap AGV ditambahkan keypad, LCD dan led indikator. Rangkaian catu daya menggunakan AKI 12V dilengkapi dengan konverter DC-DC tipe buck yang menurunkan tegangan ke $5 \mathrm{~V}$.

\section{Susunan Sensor Garis}

Mekanisme sensor pembaca garis yang dirancang menggunakan 14 buah sensor garis yang menghadap ke lantai. Jarak antar sensor sebesar 2 $\mathrm{cm}$ yang tersusun sejajar dan membentuk garis lurus

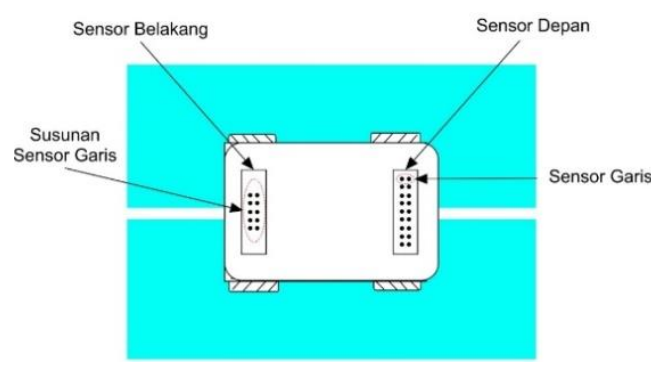

Gambar 7 susunan sensor garis dan model pemasangannya

Pemasangan sensor dibagi dalam dua tempat yaitu 9 di depan dan 5 di belakang. Sensor depan digunakan sebagai pemandu utama sedangkan 
sensor belakang digunakan untuk menjaga posisi roda belakang tetap seimbang di area jalur, sehingga dibutuhkan sensor depan lebih banyak dibandingkan yang di belakang.

\subsection{Kendali PID Adaptif}

Kendali PID yang digunakan pada sistem AGV ini dikatakan adaptif karena nilai kostanta PID dipengaruhi oleh nilai setpoint kecepatan AGV. Hubungan antara kecepatan dengan kostanta PID ditentukan menggunakan persamaan regresi polinomial yang didapatkan dari nilai PID tiga kecepatan yang berbeda yaitu $80 \mathrm{~m} / \mathrm{s}, 130 \mathrm{~m} / \mathrm{s}$ dan $180 \mathrm{~m} / \mathrm{s}$. Dalam menentukan besarnya PID pada masing-masing tiga kecepatan tersebut digunakan metode Ziegler-Nicols (ZN).

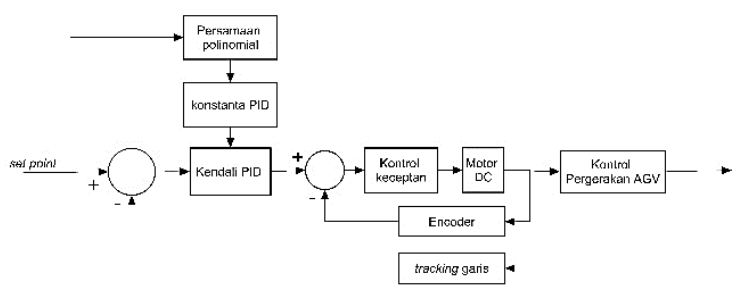

Gambar 8 blok diagram kendali PID adaptif

\section{Penentuan Konstanta PID Menggunakan Metode Ziegler-Nicols (ZN)}

Sebelum menentukan kendali PID adaptif, terlebih dahulu menentukan nilai PID menggunakan metode Ziegler-Nicols (ZN) untuk tiga nilai kecepatan yang berbeda yaitu $80 \mathrm{~m} / \mathrm{s}, 130 \mathrm{~m} / \mathrm{s}$ dan $180 \mathrm{~m} / \mathrm{s}$. Ketika sudah didapatkan konstanta PID untuk kecepatan tersebut, selanjutnya dibuat persamaan menggunakan regresi polinomial untuk menentukan nilai konstanta PID di setiap kecepatan yang lain dalam range $(60-180) \mathrm{m} / \mathrm{s}$. Dalam sistem closed loop, penggunaan metode ZN harus mencari nilai $\mathrm{K}_{\text {cr }}$ dan $\mathrm{P}_{\text {cr. }} \mathrm{K}_{\mathrm{cr}}$ didapatkan dengan cara membuat AGV berosilasi mengikuti garis dengan mengatur nilai $\mathrm{Kp}$ saja, sementara $\mathrm{Ki}$ dan Kd sama dengan 0.Data osilasi ini didapatkan dari besarnya nilai error pembacaan sensor garis ketika AGV begerak mengikuti garis. Nilai Kp inilah yang menjadi nilai $K c r$. Sementara nilai $P_{c r}$ didapatkan dari besarnya nilai periode (T) osilasi. Setelah parameter $\mathrm{K}_{\text {cr }}$ dan $\mathrm{P}_{\mathrm{cr}}$ didapatkan, nilai-nilai $\mathrm{Kp}$, Ki dan Kd dapat dihitung menggunakan rumusrumus parameter PID ZN.

Tabel 1 Ringkasan parameter fisik

\begin{tabular}{lll}
\hline $\mathrm{Kp}$ & $\mathrm{Ki}$ & $\mathrm{Kd}$
\end{tabular}

$$
0.6 K_{c r} \quad \frac{K_{p}}{0.5 P_{c r}} \quad \frac{K_{p}}{0.125 P_{c r}}
$$

Data osilasi untuk menentukan nilai $\mathrm{K}_{\mathrm{cr}}$ dan $\mathrm{P}_{\mathrm{cr}}$ didapatkan dari nilai error pembacaan sensor garis ketika AGV begerak mengikuti garis. Besarnya nilai error sesuai dengan posisi sensor garis AGV terhadap garis. Ketika sensor tengah yang dapat garis, nilai error $=0$. Satu step ke kiri error dikurang 1 dan satu step ke kanan error ditambah 1 dan seterusnya sampai sensor paling pinggir yang membaca garis.

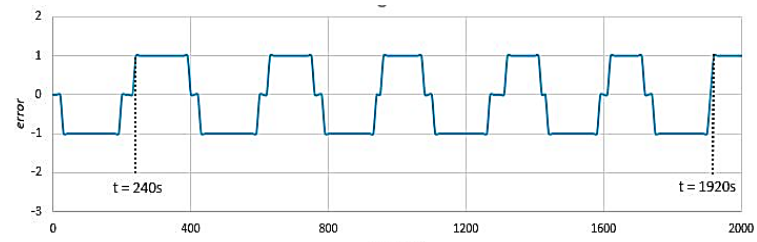

(a)

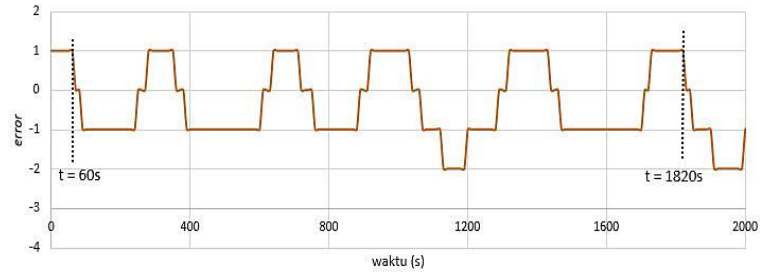

(b)

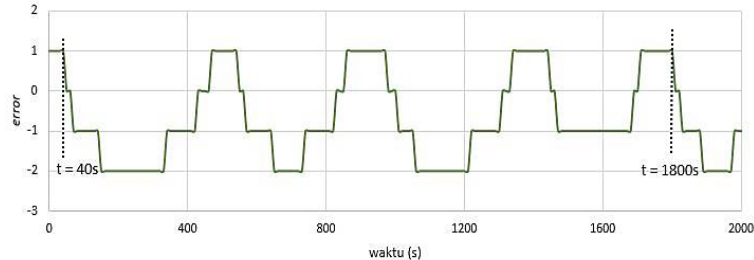

(c)

Gambar 9 osilasi error untuk menentukan nilai $\mathrm{K}_{\mathrm{cr}}(\mathrm{a})$ kecepatan $80 \mathrm{~m} / \mathrm{s}$, (b) kecepatan $130 \mathrm{~m} / \mathrm{s}$, (c) kecepatan $180 \mathrm{~m} / \mathrm{s}$

Untuk mendapatkan osilasi error terhadap garis dibuat nilai $\mathrm{Kp}=200$ untuk $80 \mathrm{~m} / \mathrm{s}, \mathrm{Kp}=140$ untuk $130 \mathrm{~m} / \mathrm{s}$ dan $\mathrm{Kp}=100$ untuk 180m/s. Pada gambar 8 terlihat, untuk mendapatkan 5 osilasi error pada kecepatan $80 \mathrm{~m} / \mathrm{s}$ dibutuhkan waktu $(1920-240) \mathrm{s}=1680 \mathrm{~s}$, sehingga T80m/s $=1680 / 5$ = 336s. Pada kecepatan $130 \mathrm{~m} / \mathrm{s}$ didapatkan waktu 1760s untuk 5 osilasi error, sehingga $T_{130 \mathrm{~m} / \mathrm{s}}$ $=1760 / 5=352$. Sementara pada kecepatan $180 \mathrm{~m} / \mathrm{s}$ dibutuhkan waktu 1760 s untuk 4 osilasi error, sehingga $\mathrm{T}_{180 \mathrm{~m} / \mathrm{s}}=1760 / 4=440$. Dari datadata tersebut besarnya nilai $\mathrm{K}_{\mathrm{cr}}$ dan $\mathrm{P}_{\mathrm{cr}}$ dapat ditentukan.

Tabel 2 nilai $\mathrm{K}_{\mathrm{cr}}$ dan $\mathrm{P}_{\mathrm{cr}}$

\begin{tabular}{ccc}
\hline Kecepatan $(\mathrm{m} / \mathrm{s})$ & $\mathrm{K}_{\mathrm{cr}}=$ Kposilasi & $\mathrm{P}_{\mathrm{cr}}=\mathrm{T}$ \\
\hline 80 & 200 & 336 \\
130 & 140 & 352 \\
\hline
\end{tabular}


Seminar Nasional Instrumentasi, Kontrol dan Otomasi (SNIKO) 2018 Bandung, Indonesia, 10-11 Desember 2018

\begin{tabular}{lll}
\hline 180 & 100 & 440
\end{tabular}

Dengan menggunakan persamaan kostanta PID metode ZN nilai Kp, Ki dan Kd dapat ditentukan.

Tabel 3 Kostanta PID metode ZN

\begin{tabular}{cccc}
\hline Kecepatan $(\mathrm{m} / \mathrm{s})$ & $\mathrm{Kp}$ & $\mathrm{Ki}$ & $\mathrm{Kd}$ \\
\hline 80 & 120 & 0.714 & 2.857 \\
130 & 84 & 0.477 & 1.909 \\
180 & 60 & 0.273 & 1.09 \\
\hline
\end{tabular}

Persamaan Regresi Polinomial Kostanta PID terhadap Kecepatan

Kecepatan AGV diatur dalam range 0.5 - $2 \mathrm{~m} / \mathrm{s}$ (Silvirianti). Dari tiga kecepatan yang sudah diketahi kostanta PID-nya dapt digunakan untuk menentukan kostanta PID kecepatan yang lain menggunakan regresi polinomial. Karena pada tabel ada tiga data untuk masing-masing kostanta maka persamaannya menggunakan polinomial pangkat 2. Rumus umumnya sebagai berikut:

$$
K=a v^{2}+b v+c
$$

Dimana: $K: K p, K i, K d$

$$
v=\text { kecepatan }
$$

$a, b, c=$ kostanta polinomial

Dengan 3 nilai kostanta berbeda untuk 3 kecepatan didapatkan persamaan matriksnya sebagai berikut:

$$
\begin{aligned}
& {\left[\begin{array}{lll}
\left(v_{1}\right)^{2} & v_{1} & 1 \\
\left(v_{2}\right)^{2} & v_{2} & 1 \\
\left(v_{3}\right)^{2} & v_{3} & 1
\end{array}\right]\left[\begin{array}{l}
a \\
b \\
c
\end{array}\right]=\left[\begin{array}{l}
K_{1} \\
K_{2} \\
K_{3}
\end{array}\right]} \\
& {\left[\begin{array}{l}
a \\
b \\
c
\end{array}\right]=\left[\begin{array}{lll}
\left(v_{1}\right)^{2} & v_{1} & 1 \\
\left(v_{2}\right)^{2} & v_{2} & 1 \\
\left(v_{3}\right)^{2} & v_{3} & 1
\end{array}\right]^{-1}\left[\begin{array}{l}
K_{1} \\
K_{2} \\
K_{3}
\end{array}\right]}
\end{aligned}
$$

Untuk mencari $\mathrm{Kp}$ digunakan persamaan (3) dengan mengambil data-data $\mathrm{Kp}$ pada tabel 3 untuk 3 kecepatan berbeda. Didaptkan persamaan kostanta $a, b, c$ sebagai berikut:

$$
\begin{gathered}
{\left[\begin{array}{l}
a \\
b \\
c
\end{array}\right]=\left[\begin{array}{ccc}
80^{2} & 80 & 1 \\
130^{2} & 130 & 1 \\
180^{2} & 180 & 1
\end{array}\right]^{-1}\left[\begin{array}{c}
120 \\
84 \\
60
\end{array}\right]} \\
{\left[\begin{array}{l}
a \\
b \\
c
\end{array}\right]=\left[\begin{array}{c}
0.024 \\
-1.224 \\
202.56
\end{array}\right]}
\end{gathered}
$$

Dengan cara yang sama, kostanta $a, b, c$ dari nilai Ki adalah sebagai berikut:

$$
\begin{gathered}
{\left[\begin{array}{l}
a \\
b \\
c
\end{array}\right]=\left[\begin{array}{ccc}
80^{2} & 80 & 1 \\
130^{2} & 130 & 1 \\
180^{2} & 180 & 1
\end{array}\right]^{-1}\left[\begin{array}{l}
0.714 \\
0.477 \\
0.273
\end{array}\right]} \\
{\left[\begin{array}{l}
a \\
b \\
c
\end{array}\right]=\left[\begin{array}{c}
7 \times 10^{-6} \\
-0.0061 \\
1.1618
\end{array}\right]}
\end{gathered}
$$

Dengan cara yang sama, kostanta $a, b, c$ dari nilai Kd adalah sebagai berikut:

$$
\begin{gathered}
{\left[\begin{array}{l}
a \\
b \\
c
\end{array}\right]=\left[\begin{array}{ccc}
80^{2} & 80 & 1 \\
130^{2} & 130 & 1 \\
180^{2} & 180 & 1
\end{array}\right]^{-1}\left[\begin{array}{c}
2.857 \\
1.909 \\
1.09
\end{array}\right]} \\
{\left[\begin{array}{l}
a \\
b \\
c
\end{array}\right]=\left[\begin{array}{c}
3 \times 10^{-5} \\
-0.0244 \\
4.6421
\end{array}\right]}
\end{gathered}
$$

Sehingga dari nilai kostanta $a, b, c$ untuk masingmasing parameter kostanta PID diadaptkan nilai $\mathrm{Kp}$, Ki dan Kd sebagai berikut:

$$
\begin{aligned}
& K_{p}=0.024 v^{2}-1.224 v+202.56 \\
& K_{i}=7 \times 10^{-6} v^{2}-0.0061 v+1.1618 \\
& K_{d}=3 \times 10^{-5} v^{2}-0.0244 v+4.6421
\end{aligned}
$$

\subsection{Waktu dan Tempat Penelitian}

Penelitian ini dilakukan dalam kurun waktu 8 bulan yaitu bulan April-November 2018. Penelitian ini dilakukan di beberapa laboratorium di Politeknik Industri Logam Morowali, antara lain: Workshop Mesin dan Laboratorium Elektronika.

\section{Hasil dan Pembahasan}

\subsection{Hasil Pengujian Arah Pergerakan AGV Menggunakan Roda Mecanum}

Pengujian arah pergerakan AGV menggunakan roda omni-directional dilakukan untuk melihat seberapa besar pergeseran sudut pergerakan AGV terhadapa nilai sudut acuan yang diberikan. Penentuan arah pergerakan AGV dikalkulasi menggunakan persamaan invers kinematik. Nilai kecepatan linear dan sudut pergerakan diatur sesuai keinginan kemudian besarnya kecepatan sudut tiap roda didapatkan berdasarkan perhitungan invers kinematik menggunakan acuan kecepatan linear AGV $\left(v_{R}\right)$, sudut pergerakan $(\theta)$ dan kecepatan angular AGV $\left(\omega_{Z}\right)$. 
Tabel 4 Perbandingan sudut pergerakan AGV dengan sudut acuan yang diberikan

\begin{tabular}{|c|c|c|c|}
\hline \multicolumn{2}{|l|}{ Sudut Acuan } & \multirow{2}{*}{$\begin{array}{c}\text { Sudut } \\
\text { pergerakan } \\
\text { AGV }\left({ }^{\circ}\right)\end{array}$} & \multirow[b]{2}{*}{ Selisih } \\
\hline Keterangan & $\begin{array}{c}\text { Sudut } \\
\left({ }^{\circ}\right)\end{array}$ & & \\
\hline Maju & 0 & -1.7 & 1.7 \\
\hline Serong kiri depan & 45 & 49.26 & 4.26 \\
\hline Ke kiri & 90 & 91.6 & 1.6 \\
\hline Serong kiri belakang & 135 & 140.08 & 5.08 \\
\hline Mundur & 180 & 183.95 & 3.95 \\
\hline Serong kanan belakang & 225 & 227.6 & 2.6 \\
\hline Ke kanan & 270 & 272.38 & 2.38 \\
\hline Serong kanan depan & 315 & 311.45 & 3.55 \\
\hline & & -rata selisih & 3.14 \\
\hline
\end{tabular}

Hasil pengujian menunjukkan rata-rata selisih sudut pergerakan AGV dengan sudut acuan sebesar $3.14^{\circ}$. Besarnya selisih ini menunjukkan sudut pergerakan AGV memiliki error yang kecil terhadap sudut acuan.

\subsection{Hasil Pengujian Kecepatan AGV dengan kendali PID Adaptif Mengikuti Garis}

Pengujian kecepatan AGV dalam mengikuti garis didapatkan dengan menguji pengaruh kestabilan pergerakan AGV dengan kendali PID Adaptif mengikuti garis terhadap besarnya kecepatan roda. Kecepatan AGV diatur dari nilai $0.6 \mathrm{~m} / \mathrm{s}$ sampai 2 $\mathrm{m} / \mathrm{s}$ dengan kenaikan $0.2 \mathrm{~m} / \mathrm{s}$.

Ada tiga kriteria kestabilan yang didapatkan dari pembacaan 9 (Sembilan) sensor pada modul sensor garis bagian depan. Cara penentuan kriterianya adalah sebagai berikut:

- Stabil, yaitu minimal satu sensor dari tiga sensor garis di tengah yang membaca garis.

- Kurang stabil, yaitu kondisi stabil tidak terpenuhi, namun salah satu dari 9 sensor ada yang membaca garis.

- Tidak stabil, yaitu pernah tidak ada sensor yang membaca garis.

Tabel 5 Pengaruh kestabilan pergerakan AGV mengikuti garis terhadap nilai kecepatan roda

\begin{tabular}{ccc}
\hline $\begin{array}{c}\text { Kecepatan Roda } \\
\text { AGV(m/s) }\end{array}$ & $\begin{array}{c}\text { Kondisi } \\
\text { Kecepatan }\end{array}$ & $\begin{array}{c}\text { Kestabilan } \\
\text { Pergerakan AGV }\end{array}$ \\
\hline 0.5 & lambat & Stabil \\
0.8 & & Stabil \\
1 & Sedang & Stabil \\
\hline 1.2 & & Stabil \\
1.4 & & Stabil \\
1.6 & cepat & Stabil \\
1.8 & & Kurang stabil \\
\hline 2 & &
\end{tabular}

Dari data terlihat kondisi perubahan kecepatan dibagi dalam tiga kelompok kecepatan yaitu lambat, sedang dan cepat. Pergerakan AGV stabil mengikuti garis meskipun nilai kecepatan berubahubah pada kondisi lambat dan sedang namun pada kondisi cepat, AGV kurang stabil pada kecepatan 2 $\mathrm{m} / \mathrm{s}$.

Dipilih nilai pengujian kecepatan dari 0.5 - $2 \mathrm{~m} / \mathrm{s}$. Pengujian ini sejalan dengan pernyataan Silvirianti et al (2017), bahwa kecepatan AGV rata-rata dari 0.5 - $2 \mathrm{~m} / \mathrm{s}$. Dengan kondisi kurang stabilnya AGV pada kecepatan $2 \mathrm{~m} / \mathrm{s}$ dalam mengikuti garis, sehingga diambil pergerakan AGV berada pada range kecepatan 0.5 - 1.8 m/s. Kecepatan ini tergolong rendah jika dibandingkan kendaraan lain, karena AGVs sering beroperasi di daerah di mana orang bekerja sehingga sistem keselamatan yang dirancang khusus mudah menghentikannya secara terkendali (Silvirianti et al., 2017).

\subsection{Hasil Pengujian AGV Mengambil dan Menyimpan Toolbox di Station}

Pengujian mengambil toolbox dari station dilakukan dengan menempatkan AGV dari luar area station, kemudian bergerak untuk mengambil toolbox. Kondisi berhasil mengambil toolbox diperoleh ketika toolbox terambil secara sempurna, sehingga lepas dari station dan AGV keluar dari area station. Pengujian menyimpan toolbox ke station dilakukan dengan menempatkan AGV dari luar area station dengan posisi toolbox ada di AGV, kemudian bergerak menuju station untuk menyimpan toolbox. Kondisi berhasil menyimpan toolbox diperoleh ketika toolbox terpasang sempurna pada station, sehingga lepas dari AGV kemudian AGV kembali keluar dari area station.

Tabel 6 Pengujian AGV mengambil dan menyimpan toolbox di station

\begin{tabular}{cccccc}
\hline Kondisi & \multicolumn{6}{c}{ Percobaan ke } \\
\cline { 2 - 6 } & 1 & 2 & 3 & 4 & 5 \\
\hline $\begin{array}{c}\text { Mengambil } \\
\text { toolbox }\end{array}$ & $\sqrt{ }$ & $\sqrt{ }$ & $\sqrt{ }$ & $\sqrt{ }$ & $\sqrt{ }$ \\
\hline $\begin{array}{c}\text { Menyimpan } \\
\text { toolbox }\end{array}$ & $\sqrt{ }$ & $\sqrt{ }$ & $\sqrt{ }$ & $\sqrt{ }$ & $\sqrt{ }$ \\
\hline
\end{tabular}

Pada tabel pengujian AGV mengambil dan menyimpan toolbox di station terlihat bahwa dari kelima percobaan yang dilakukan AGV berhasil mengambil dan menyimpan toolbox di station.Data ini menggambarkan bahwa model AGV, toolbox dan station yang dirancang untuk sistem mengambil 
dan menyimpan alat pada penelitian ini dapat digunakan.

\section{Kesimpulan}

Kesimpulan yang dapat ditarik pada hasil penelitian ini adalah sebagai berikut:

- Sistem AGV menggunakan roda omni-directional tipe mecanum dapat dirancang.

- Penggunaan kendali PID Adaptif efektif digunakan untuk memandu AGV mengikuti dengan kecepatan AGV (0.5 - 1.8) m/s.

- Model AGV, station dan toolbox dapat digunakan

\section{Daftar Pustaka}

Pada teks, dafar pustaka harus disitasi dengan menuliskan no urut daftar pustaka

Contoh penulisan daftar pustaka :

[1] Apple J.M., Plant Layout and Material Handling.. , Jilid 3, Wiley. New York, 1977.

[2] Badan Penelitian dan Pengembangan Industri (BPPI), Kebijakan Industri Nasional di Era Disrupsi Teknologi, 2018.

[3] Barbulescu V., et al., EncoderBased Path Tracking With Adaptive Cascaded Control For A Three Omni-Wheel Robot., IEEE International Conference of Networking in Education and Research (RoEduNet):1 - 6, 2017.

[4] Draganjac I., et al., Decentralized Control of Multi-AGV Systems in Autonomous Warehousing Applications., IEEE Transactions on Automotion Science and Engineering. 13(4): 1433 - 1447, 2016.
[5] Gomes M.V.,et al., PID Control applied on a linefollower AGV using a RGB camera. IEEE 19th International Converence on Intelligent Transportation Systems (ITSC):194-198, 2016.

[6] Kun F., et al., On The Design Of AGV Obstacle Avoidance System Based On Fuzzy-PID DualMode Controller, IEEE Conference on Control, Systems \& Industrial Informatics (ICCSII):5458, 2012.

[7] Nugraha M.B., Ardianto P.R., and Darlis D., Design and implementation of RFID linefollower system with color detection capability using fuzzy logic, IEEE International Conference on Control, Electronics, Renewable Energy and Communications (ICCEREC):75-78, 2015.

[8] Piyare R.K., and Singh R., Wireless Control of an Automated Guided Vehicle., Proceedings of the International Multi Conference of Engineers and Computer Scientists (IMECS) 2: 828 - 833, 2011.

[9] Silvirianti et al., Speed Control System Design Using Fuzzy-PID for Load Variation of Automated Guided Vehicle (AGV)., IEEE International Conferences on Frontiers of Sensors Technologies:426-430, 2017.

[10]Tsai C.C., et al., Decentralized cooperative transportation with obstacle avoidance using fuzzy wavelet neural networks for uncertain networked omnidirectional multi-robots., IEEE International Conferences on Control and Automation (ICCA):978-983, 2016.

[11]Wicaksono $H$, and Nilkhamhang I., Glocal Controller-based Formation Control Strategy for Flexible Material Handling., IEEE International Conference of the Society of Instrument and Control Engineers (SICE): 787-792, 2017.

[12]World Economic Forum., The Global Competitiveness Report 2015 - 2016, 2016. 